\title{
Genetic polymorphism of COL1A1 gene and bone mineralisation in juvenile idiopathic arthritis
}

\author{
MM Kostik ${ }^{*}$, GS Demin², GV Stoyko², LA Scheplyagina ${ }^{3}$, VI Larionova $^{1}$ \\ From 18th Pediatric Rheumatology European Society (PReS) Congress \\ Bruges, Belgium. 14-18 September 2011
}

\section{Background}

Bone mineralization disturbances are common in children with juvenile idiopathic arthritis (JIA) and depend on inflammation, medications, lack of motion and genetic factors.

\section{Aim}

To evaluate the role of genetic markers in bone metabolism and mineralization in JIA children.

\section{Methods}

We included 196 JIA children, 81 boys and 115 girls. Bone mineralization parameters were detected by dual-energy $\mathrm{X}$-ray absorptiometry of lumbar spine $\mathrm{L}_{1}-\mathrm{L}_{4}$. Bone biochemical markers were osteocalcine, C-terminal telopeptides (CTT), parathyroid hormone (PTH), $\mathrm{Ca}, \mathrm{Ca}^{++}, \mathrm{P}$, total alkaline phosphatase (TAP) activity. We have detected Sp1 (rs1800012) and -1997G/T (rs1107946) polymorphisms in type I alpha-1 chain collagen gene (COL1A1).

\section{Results}

We revealed gender differences in Sp1 genotype distribution in children with low bone mineral density (LBMD): boys had GG genotype in $89.5 \%$ and girls in $54.2 \%$ $(\mathrm{p}=0.03)$. In boys GG genotype presence increased LBMD - OR=2.96 (95\%CI: 0.59-14.9) compare in girls in which GG presence decreased LBMD - OR $=0.56(95 \%$ CI: 0.36-2.7). Also, children carried T allele (GT and TT genotypes) despite on higher inflammatory parameters had better mineralization dates. In total group children with GG genotype had higher osteocalcine (111.0 $\pm 56.1 \mathrm{ng} \backslash \mathrm{ml}$ and $85.9 \pm 39.9 \mathrm{ng} / \mathrm{ml}$ in $\mathrm{GT}+\mathrm{TT}, \mathrm{p}=0.02$ ) and CTT levels $(1.22 \pm 0.45 \mathrm{ng} \backslash \mathrm{ml}$ and $0.99 \pm 0.38 \mathrm{ng} \backslash \mathrm{ml}$ in

\footnotetext{
* Correspondence: kost-mikhail@yandex.ru

${ }^{1}$ State Pediatric Medical Academy, Saint-Petersburg, Russian Federation

Full list of author information is available at the end of the article
}

$\mathrm{GT}+\mathrm{TT}, \mathrm{p}=0.02$ ). In children, who have not been treated with steroids GG genotype was associated with lower BMD-Zscore in boys $(-1.24 \pm 0.14 \mathrm{SD}$ and $0.29 \pm 0.98 \mathrm{SD}$ in $\mathrm{GT}+\mathrm{TT}, \mathrm{p}=0.006)$ and lower height in girls $(142.9 \pm$ $28.0 \mathrm{~cm}$ and $156.3 \pm 21.6 \mathrm{~cm}$ in GT+TT, $\mathrm{p}=0.025$ ). In children with Tanner stage I GG genotype was associated with more rare LBMD ( $12.8 \%$ vs $36.4 \%$ in GT+TT, $\mathrm{p}=0.05)$ and with frequent LBMD in children with Tanner stage II-III ( $37.8 \%$ and $5.9 \%$ in GT+TT, $\mathrm{p}=0.01$ ).

GG genotype of -1997G/T polymorphism was associated with lower $\mathrm{Ca}^{++}(1.1 \pm 0.11 \mathrm{mmol} / \mathrm{l}$ and $1.15 \pm 0.006 \mathrm{mmol} / \mathrm{l}$ in $\mathrm{GT}+\mathrm{TT}, \mathrm{p}=0.03)$, inorganic phosphate $(1.67 \pm$ $0.16 \mathrm{mmol} / \mathrm{l}$ and $1.57 \pm 0.22 \mathrm{mmol} / \mathrm{l}$ in GT+TT, $\mathrm{p}=0.04$ ) and osteocalcine level $(82.3 \pm 18.4 \mathrm{ng} / \mathrm{ml}$ and $115.5 \pm$ $24.2 \mathrm{ng} / \mathrm{ml}, \mathrm{p}=0.01$ ) in children with Tanner stage II-III and lower BMD $\left(0.84 \pm 0.14 \mathrm{~g} \backslash \mathrm{cm}^{2}\right.$ and $0.91 \pm 0.1$ in $\mathrm{GT}+\mathrm{TT}, \mathrm{p}=0.04)$ and lower BMD-Zscore $(-1.275 \pm 1.25 \mathrm{SD}$ and $-0.5 \pm 1.0 \mathrm{SD}$ in $\mathrm{GT}+\mathrm{TT}, \mathrm{p}=0.009$ )

\section{Conclusion}

We have revealed different changes in mineralization and metabolism, associated with sex, Tanner stage and treatment due to COL1A1 gene polymorphisms in children.

\section{Author details \\ ${ }^{1}$ State Pediatric Medical Academy, Saint-Petersburg, Russian Federation. ${ }^{2 " G e n e " ~ L t d, ~ S a i n t-P e t e r s b u r g, ~ R u s s i a n ~ F e d e r a t i o n . ~}{ }^{3}$ Federal scientific and clinical center of pediatric haemotology, oncology and immunology, Moscow, Russian Federation.}

Published: 14 September 2011

doi:10.1186/1546-0096-9-S1-P310

Cite this article as: Kostik et al:: Genetic polymorphism of COL1A1 gene and bone mineralisation in juvenile idiopathic arthritis. Pediatric

Rheumatology 2011 9(Suppl 1):P310. 